\title{
Endoscopic cyclophotocoagulation in refractory glaucomas: a long term study
}

\section{Ciclofotocoagulação endoscópica em glaucomas refratários com longo tempo de seguimento}

Francisco Eduardo Lima ${ }^{1,2,3}$, José Beniz Neto ${ }^{1,2}$, Daniela Toscano ${ }^{3}$, Durval Moraes de Carvalho ${ }^{2,3}$, Marcos Pereira de Ávila $a^{1,2,3}$

ABSTRACT
Purpose: To evaluate the safety and efficacy of endoscopic cyclophotocoagulation (ECP)
in the treatment of refractory glaucomas. Methods: The preoperative and postoperative
courses of 539 eyes of 539 patients with refractory glaucoma who underwent ECP and
had a minimum 5 years follow-up were retrospectively reviewed. All procedures were
performed by a single surgeon (FEL). Eyes that were included had undergone at least
one incisional glaucoma surgery and had intraocular pressure (IOP) equal to or above
35 mmHg on maximum tolerated medical therapy, and a visual acuity better than light
perception. Success was defined as IOP greater than 6 mmHg and lower than 22 mmHg
after 5 years postoperatively, with or without topical anti-hypertensive therapy. ECP
included $210^{\circ}$ of the ciliary body, corresponding to 2 to 9 hours in the right eye and from
3 to 10 hours in the left eye, including the anterior third of the pars plana. Results: The
mean follow-up was $88.9 \pm 10.3$ months (range 60 to 108 months). Mean preoperative
IOP was $38.1 \pm 6.5$ mmHg, and postoperative IOP was $12.1 \pm 3.4$ mmHg, with or without
topical antiglaucomatous medication (p<0.05). The mean number of glaucoma
medications used by each patient was reduced from $3.9 \pm 1.2$ preoperatively to $1.9 \pm 1.4$
postoperatively (p< 0.05 ). Best corrected visual acuity was stable or improved
postoperatively in 407 eyes ( $95.3 \%)$ while 20 eyes ( $4.7 \%)$ lost 2 or more lines of Snellen
acuity. The success rate at 12 and 60 months were, $92.5 \%$ and $79 \%$ respectively. Kaplan-
Meier survival analysis showed an overall probability of success at 60 months of $71.5 \%$.
Complications included fibrin exudation in 116 eyes ( $21.5 \%$ ), hyphema in 58 eyes
(10.7\%), choroidal detachment in 31 eyes (5.7\%), phthisis in 13 eyes ( $2.4 \%)$, retinal
detachment in 8 eyes (1.4\%) and hypotony in 7 eyes (1.2\%).Conclusion: These results
suggest that ECP is a safe and effective therapeutic modality for refractory glaucomas
after a long-term follow-up.

Keywords: Glaucoma/surgery; Laser coagulation/methods; Fotocoagulation/methods; Visual acuity; Intraocular pressure

${ }^{1} \mathrm{MD}$, Universidade Federal de Goiás - UFG - Goiânia (GO), Brazil;

${ }^{2} \mathrm{MD}$, Centro Brasileiro de Cirurgia de Olhos - Goiânia (GO), Brazil;

${ }^{3} \mathrm{MD}$, Centro Brasileiro da Visão - Brasília (DF), Brazil.

Recebido para publicação em: 20/5/2009 - Aceito para publicação em 28/7/2009 


\section{INTRODUCTION}

G laucoma is the second leading cause ofblindness worldwide $^{(1)}$. Cyclodestructive procedures have been used to treat glaucoma in patients for whom conventional filtration surgery has failed or has a poor predicted outcome $e^{(2,3)}$.

Ablation of the ciliary body lowers intraocular pressure by decreasing the secretion of aqueous humor ${ }^{(4-6)}$.

Most cyclodestructive procedures are performed by means of the transscleral route, either by freezing the ciliary body or by coagulating it with laser energy. However, this approach is limited by significant complications, treatment failure, and hypotony. These difficulties arise from the inability to visualize the ciliary process during the treatment, resulting in over - or under treatments as well as incorporation of non-aqueous producing tissue in the treatment zone. ${ }^{(4,5)}$

Endoscopic cyclophotocoagulation (ECP) has the unique ability of simultaneous visualization and treatment of the ciliary body through a pars plana or anterior chamber approach; it offers the possibility of selectively treating the ciliary body epithelium. On the other hand the disadvantage is the learning curve, the risk of lens damage in a phakic eye, zonular damage, and the risk inherent in any intraocular procedure. ${ }^{(8)}$ Uram described the technique of diode laser cyclophotocoagulation through an endoscopic system in 1992, reporting a series of 10 patients with neovascular glaucoma $^{(7)}$.

Trevisani et al. ${ }^{(10)}$ had carried out histological comparison between eyes treated with ECP and transscleral cyclophotocoagulation, and had concluded that the endoscopic route caused focal ablation of the ciliary epithelium, without destruction of the ciliary muscle while the transscleral route provoked coagulative alterations in stroma and in the ciliary muscle.

Due to the lack of studies evaluating long term follow up, the purpose of our study is to evaluate the safety and efficacy of ECP in the treatment of refractory glaucoma.

\section{Methods}

This was a retrospective, non-comparative study. The office charts off all patients who underwent ECP at Centro Brasileiro de Cirurgia de Olhos and Federal University of Goiás, Brazil, between 1995 and 2001, and had minimum 5 years follow-up were restrospectively reviewed. A signed informed consent and Ethics
Committee approval from the institutions were obtained before any patient enrollment. Patients were informed of the invasive nature of ECP and a written consent was obtained.

Eyes included had at least one intraocular glaucoma surgery and an intraocular pressure (IOP) greater than or equal to $35 \mathrm{mmHg}$ on maximum tolerated therapy or eyes with advanced glaucomatous damage and IOP greater than target pressure, and visual acuity better than light perception. Exclusion criteria included eyes that had a previous cyclodestructive procedure, eyes that did not perceive light, eyes that had a retinal or choroidal detachment or eyes with failed corneal graft.

All surgeries were performed by a single experienced surgeon (FEL). Success was defined as an IOP greater than $6 \mathrm{mmHg}$ and bellow to $22 \mathrm{mmHg}$ at last follow-up visit with or without maximum tolerated topical antiglaucomatous therapy. Failure treatment was defined as an IOP greater or equal to $22 \mathrm{mmHg}$ during 3 consecutive postoperative visits, eyes that went to $p h t h i s i s$ bulbi, and eyes that had to undergo another surgical intervention to control IOP. Patients who reached the failure endpoint were censored from further analysis. However, their IOP was included in the average IOP calculation at this time.

All patients underwent a thorough ophthalmic evaluation including a LogMar visual acuity, slitlamp biomicroscopy and dilated retinal exam. An ultrasound exam was performed when the media was not clear. Demographic data such as age and sex were collected. Three different physicians measured the IOP with the Goldmann tonometer in the morning, always around 10 o'clock. The IOP was considered as a single measured by one of the observers.

The ECP was done with a commercially available device (MicroPobre,ENDOOPTIKS, Little SILVER, NJ, USA) with an endoscope with a 110-degree field of view and a focal distance of $0.75 \mathrm{~mm}$ to infinity, camera and an $810 \mathrm{~nm}$ wavelength diode laser source with maximum power of $1.2 \mathrm{~W}$. The procedure was performed by a superior temporal pars plana incision, $3.5 \mathrm{~mm}$ from the limbus in pseudophakic eyes. In phakic eyes the ECP was done after phacoemulsification and before IOP implantation, via limbus, through the capsular bag using viscoelastic (Sodium Hyaluronate 1\%, Healon ${ }^{\circledR}$, AMO inc, Uppsala, Sweden) to open space to the endoscopic probe. In aphakic eyes the ECP was also done via the limbus. Anterior vitrectomy was accomplished in pseudophakic eyes and aphakic ones when necessary. Laser power of $0.5 \mathrm{~W}$ in the continuous wave mode produced both whitening and shrinkage of the ciliary processes. Laser power and/ 
Table 1

Glaucoma diagnosis of 539 eyes treated with ECP

\begin{tabular}{lrr}
\hline Glaucoma classifications & Frequency & $\mathbf{\%}$ \\
\hline Aphakic & 15 & 2.8 \\
Congenital & 20 & 3.7 \\
Neovascular & 93 & 17.3 \\
Associated with penetrating keratoplasty & 65 & 12.1 \\
POAG or PCAG and cataract & 112 & 20.8 \\
Pseudophakic & 172 & 31.9 \\
Associated to uveitis & 26 & 4.8 \\
Associated to vitreo-retinal disorders & 36 & 6.7 \\
Total & $\mathbf{5 3 9}$ & $\mathbf{1 0 0 . 0}$ \\
\hline
\end{tabular}

$\mathrm{POAG}=$ primary open-angle glaucoma $; \mathrm{PCAG}=$ primary closed angle glaucoma

Table 2

Postoperative complications of ECP in 539 eyes

\begin{tabular}{lrrr}
\hline Complications & Eyes(n) & \% & Total of eye \\
\hline Fibrin exudates & 116 & 21.5 & 539 \\
Hyphema & 58 & 10.7 & 539 \\
Choroidal detachment & 31 & 5.7 & 539 \\
Failure of corneal graft & 13 & 20 & 65 \\
Phthisis & 13 & 2.4 & 539 \\
Retinal detachment & 8 & 1.4 & 539 \\
Hypotony & 7 & 1.2 & 539 \\
\hline
\end{tabular}

or duration were decreased if tissue explosion was observed. ECP was applied to $210^{\circ}$ of the ciliary body, typically from 2:00 to 9:00 in the right eye and from 3:00 to 10:00 in the left eye, including the anterior third of the pars plana. Additionally, external scleral depression over the ciliary body was performed to reach the entire ciliary process and the valleys between the crests. Subconjunctival injection of tobramycin and dexamethasone was performed after procedure. Additionally, $0.1 \mathrm{ml}$ of dexamethasone was injected in the anterior chamber. Topical antibiotics, corticosteroids and atropine were prescribed postoperatively and tapered as the intraocular inflammation decreased. The antiglaucomatous medications were kept when necessary.

Statistical software SPSS was used to analyze the results. Preoperative and postoperative values were compared using Student t test. A Kaplan-Meier survival curve was created for success of IOP over time. Microsoft Excel was used to generate graphs and tables.

\section{$\underline{\text { RESULTS }}$}

Five hundred thirty nine patients were treated with endoscopic cyclophotocoagulation (ECP). Two hundred eighty eight $(53.4 \%)$ female and $251(46.6 \%)$ male patients ranging from 4 to 80 years of age (mean age 62 \pm 14 years). Their underlying diagnoses were summarized in Table 1. All patients had undergone at least one previous glaucoma surgery (mean $2 \pm 1$ surgeries).

One hundred twelve $(20.8 \%$ ) eyes did not have 5 years follow-up because of treatment failure and were counted as failed; of which 2 eyes had aphakic glaucoma, 15 eyes had congenital glaucoma, 14 had neovascular glaucoma, 18 eyes had glaucoma associated with penetrating keratoplasty, 19 eyes had undergone combined surgery of cataract and glaucoma, 36 eyes had pseudophakic glaucoma, 2 eyes had glaucoma associated to uveitis and 6 eyes had glaucoma associated to vitreoretinal disorders. For the 427 of the 539 eyes considered success and included in this analysis, follow-up ranged 


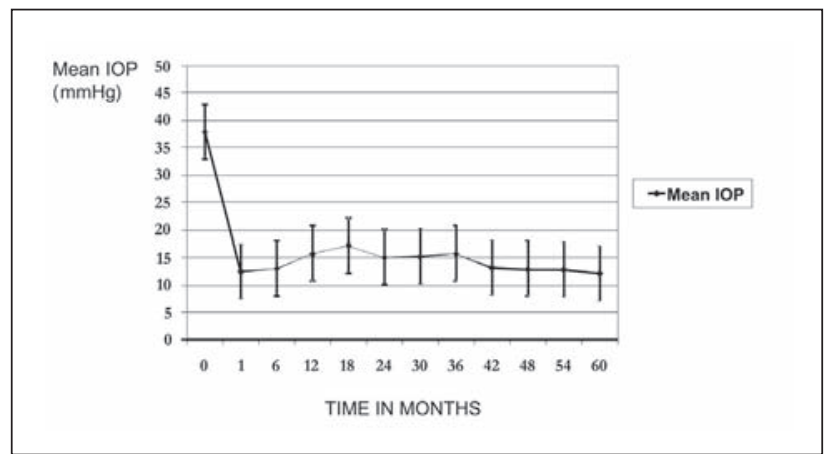

Figure 1- Mean + SD intraocular pressure (IOP) of 427 eyes with a mean follow-up of $88.9 \pm 10.3$ months (ranged from 60 to 108 months) plotted as a function of time after ECP

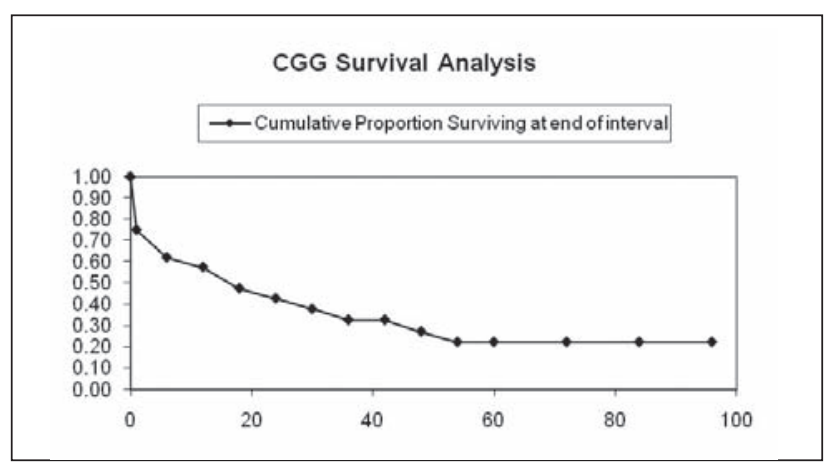

Figure 3 - Kaplan-Meier estimate of time to failure after ECP eyes with congenital glaucoma (CGC)

from 60 to 108 months, with a mean of $88.9 \pm 10.3$ months.

Of the 427 eyes the mean preoperatively IOP was $38.1 \pm 6.5 \mathrm{mmHg}$, at 1 month mean postoperative IOP was $12.4 \pm 3.4 \mathrm{mmHg}$ and at the last visit the mean postoperative IOP was $12.1 \pm 3.4 \mathrm{mmHg}$ with or without topical anti-glaucomatous medication (Figure 1). The difference between preoperative and postoperative IOP was statistically significant in all visits $(\mathrm{p}<0.05)$. Only $8.7 \%$ of the 539 eyes had IOP higher than $22 \mathrm{mmHg}$ at the first postoperative day.

The mean number of glaucoma medications used by each patient, including oral acetazolamide, was reduced from $3.9 \pm 1.2$ preoperatively to $1.9 \pm 1.4$ at the last postoperatively visit $(\mathrm{p}<0.05)$. The number of medications was decreased in 423 eyes (99\%), unchanged in 4 eyes $(1 \%)$ and did not increased in any eye. 94 eyes $(22 \%)$ were controlled without medication.

Best corrected visual acuity was stable or improved postoperatively in 407 eyes $(95.3 \%)$ and 20 eyes $(4.7 \%)$ lost 2 or more lines of Snellen acuity.

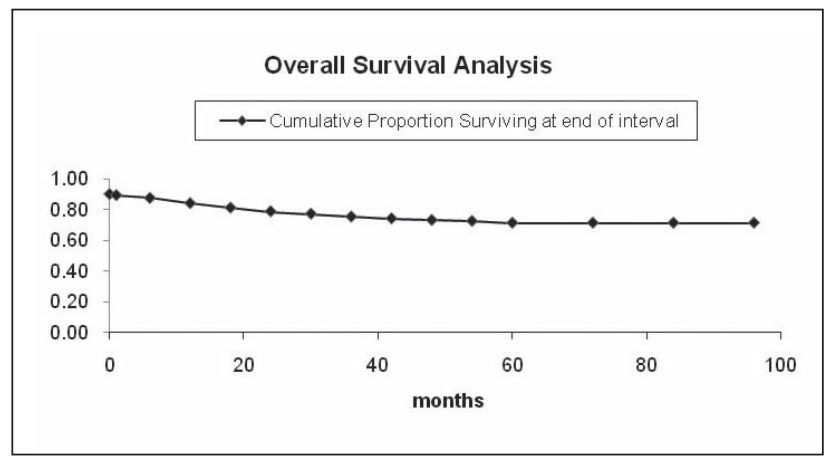

Figure 2 - Kaplan-Meier estimate of time to failure after ECP in all eyes

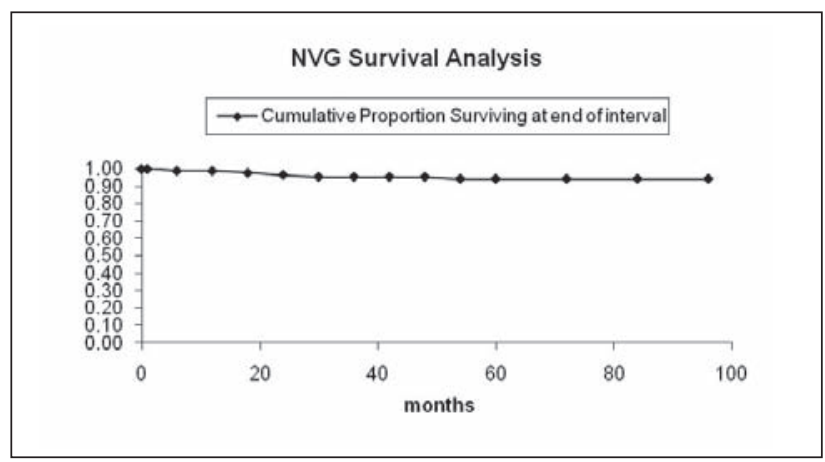

Figure 4 - Kaplan-Meier estimate of time to failure after ECP in eyes with neovascular glaucoma (NVG)

The success rate at 12 and 60 months were respectively, $92.5 \%$ and $79 \%$. Kaplan-Meier survival analysis showed probability of success at 60 months of $71.5 \%$ (Figure 2). For patients with congenital glaucoma the cumulative proportion surviving at the end of 5 year was $22 \%$, and for neovascular glaucoma was $94 \%$ (Figures 3 and 4 ).

Postoperative complications that occurred during the study are listed on Table 2 . The two most commom complications, fibrin exudates (116 eyes, $21.5 \%$ ) and hyphema (58 eyes, $10.7 \%$ ) occurred in eyes with neovascular glaucoma. Among 13 eyes that went to phthisis bulbi 10 of them had neovascular glaucoma.

\section{Discussion}

Refractory glaucoma is a subset of the disease where conventional surgical treatment has failed. ${ }^{(2,9)}$ It has been demonstrated that ECP is a safe alternative to achieve a satisfactory IOP control by decreasing the 
aqueous humor production without causing widespread damage to the ciliary body and adjacent structures as occurs with transscleral procedures. ${ }^{(10-12)}$

Previous reports suggest that ECP is a safe and effective procedure in refractory glaucoma patients after failure of conventional filtration surgery. ${ }^{(2,11,12,14)}$ Lima et al. ${ }^{(2)}$ compared the use of Ahmed Valve and ECP in 68 patients with refractory glaucoma and found, in the ECP group, a success rate of $82.35 \%$ and $73.52 \%$ at 12 and 24 months, respectively. Ahmed Valve group had similar success rate. In our study, the overall success rate was $92.57 \%$ and $78.84 \%$ at 1 and 5 years of follow-up, respectively. Gayton et al. ${ }^{(13)}$ compared cataract surgery combined with trabeculectomy or ECP. The ECP cases did not achieve an immediate reduction in IOP, as the trabeculectomy cases did. However, by 1 month, both groups stabilized at about $16 \mathrm{mmHg}$ and less complications were observed in ECP group.

Chen et al. ${ }^{(12)}$ analyzed retrospectively 68 patients with diverse forms of glaucoma who had undergone ECP. The follow-up period was 12.9 months and the mean IOP decreased $10.7 \mathrm{mmHg}$. The mean number of medication preoperatively was 3 and postoperatively was 2 , and the visual acuity remained stable in $94 \%$ of the cases. The present study demonstrated a mean IOP reduction by $25.6 \mathrm{mmHg}$, the postoperative number of glaucoma medication and the visual acuity stability were similar to the above-mentioned study.

$\mathrm{Uram}^{(7)}$ described the use of ECP in 10 intractable neovascular glaucoma with the mean follow-up of 12 months. The IOP dropped $67.6 \%$ which was similar to the present study. It is important to notice that $\operatorname{Uram}^{(7)}$ just analyzed neovascular glaucoma which seems to be associated with the biggest index of success, as the survival curve shows. However, the great majority of phthisis bulbi were among eyes with neovascular glaucoma.

The most common complication in our study was fibrin exudates $(21.5 \%)$, followed by hyphema $(10.7 \%)$ and immediate postoperative IOP spikes $(9.8 \%)$. Chen et al. ${ }^{(12)}$ reported a $24 \%$ incidence of fibrin exudates, $12 \%$ of hyphema and no phthisis bulbi. Probably the anterior chamber injection of dexamethasone performed as a routine in the present study has decreased the inflammation observed in the early postoperative period. In the present study, the sample that showed the lowest cumulative proportion surviving was congenital glaucoma.

Neely et al. ${ }^{(11)}$ reported the use of the ECP in 36 eyes with pediatric glaucoma with a mean follow-up of
19.2 months. The survival curve for the first procedure in each eye demonstrated a high rate of early treatment failure in the first postoperative year, the survival curve flattened significantly after 14 months, similarly to the present study.

\section{Conclusion}

Although this is a retrospective study, the sample size and the long follow-up time provide reliable results. ECP not only resulted in satisfactory IOP, but also preserved visual acuity in the majority of the cases. These facts associated with low incidence of complications make ECP a safe and effective procedure in the treatment of refractory glaucomas.

\section{Resumo}

Objetivo: Avaliar a segurança e a eficácia da técnica de ciclofotocoagulação endoscópica (CFE) no tratamento de glaucomas refratários. Métodos: As condições pré e pós-operatórias de 539 olhos de 539 pacientes portadores de glaucomas refratários que foram submetidos a CFE e com, no mínimo, 5 anos de seguimento foram retrospectivamente estudadas. Todas as cirurgias foram realizadas por um único cirurgião (FEL). Os olhos incluídos haviam sido submetidos a uma ou mais cirurgias anti-glaucomatosas incisionais e apresentavam pressão intraocular (PIO) igual ou superior a $35 \mathrm{mmHg}$ com medicação máxima tolerada e acuidade visual melhor que percepção luminosa. Sucesso foi definido como PIO maior que $6 \mathrm{mmHg}$ e inferior a $22 \mathrm{mmHg}$ na última visita, com ou sem medicação anti-glaucomatosa tópica. CFE incluiu $210^{\circ}$ dos processos ciliares; das 2 às 9 horas em olho direito e das 3 às 10 horas em olho esquerdo, incluindo o terço anterior da pars plana. Resultados: O tempo de seguimento médio foi $88,9 \pm 10,3$ meses (variando entre 60 e 108 meses). PIO média prée pós-operatória foi $38,1 \pm 6,5 \mathrm{mmHg}$ e 12,1 $\pm 3,4 \mathrm{mmHg}$, respectivamente, com ou sem medicação antiglaucomatosa tópica $(p<0,05)$. O número médio medicações anti-glaucomatosas foi reduzido de 3,9 \pm 1,2 no pré-operatório para $1,9 \pm 1,4$ na última visita $(p<0,05)$. A acuidade visual ficou estável ou melhorou em após a CFE em 407 olhos (95,3\%) e 20 olhos (4,7\%) perderam 2 ou mais linhas na tabela de Snellen. Os indices de sucesso aos 12 e 60 meses de pós-operatório foram $92,5 \%$ e $79 \%$, respectivamente. A curva de sobrevivência de Kaplan-Meier mostrou probabilidade de sucesso de $71,5 \%$ aos 60 meses. Como complicações fo- 
ram observados intensa reação inflamatória em 116 olhos (21,5\%), hifema em 58 eyes $(10,7 \%)$, descolamento de coróide em 31 olhos (5,7\%), phthisis bulbi em 13 olhos $(2,4 \%)$, descolamento de retina em 8 olhos $(1,4 \%)$ e hipotonia em 7 eyes (1,2\%).Conclusão: Estes resultados sugerem que CFE é uma técnica segura e eficaz para o tratamento de glaucomas refratários após longo tempo de seguimento.

Descritores: Glaucoma/cirurgia; Coagulação por laser/métodos; Fotocoagulação/métodos; Acuidade visual; Pressão intra-ocular

\section{REFERENCES}

1. Quigley HA, Broman AT. The number of people with glaucoma worldwide in 2010 and 2020. Br J Ophthalmol. 2006;90(3):262-7. Comment in: Br J Ophthalmol. 2006;90(3):253-4.

2. Lima FE, Magacho L, Carvalho DM, Susanna R Jr, Avila MP. A prospective, comparative study between endoscopic cyclophotocoagulation and the Ahmed drainage implant in refractory glaucoma. J Glaucoma. 2004;13(3):233-7.

3. Syed HM, Law SK, Nam SH, Li G, Caprioli J, Coleman A. Baerveldt-350 implant versus Ahmed valve for refractory glaucoma: a case-controlled comparison. J Glaucoma. 2004;13(1):38-45.

4. Hampton C, Shields MB, Miller KN, Blasini M. Evaluation of a protocol for transscleral neodymium: YAG cyclophotocoagulation in one hundred patients. Ophthalmology. 1990;97(7):910-7.

5. Shields MB, Shields SE. Noncontact transscleral Nd: YAG cyclophotocoagulation: a long-term follow-up of 500 patients. Trans Am Ophthalmol Soc. 1994;92:271-83; discussion 283-7.
6. Shields MB, Chandler DB, Hickingbotham D, Klintworth GK. Intraocular cyclophotocoagulation. Histopathologic evaluation in primates. Arch Ophthalmol. 1985;103(11):1731-5.

7. Uram M. Ophthalmic laser microendoscope ciliary process ablation in the management of neovascular glaucoma. Ophthalmology. 1992;99(12):1823-8.

8. Uram M. Endoscopic cyclophotocoagulation in glaucoma management. Curr Opin Ophthalmol. 1995;6(2):19-29.

9. Allingham RR, Shields MB, Damji KF, Freedman S, Moroi SE, Shafranov G. Shields' textbook of glaucoma. 5th ed. Philadelphia: Lippincott Williams \& Wilkins; 2005.

10. Trevisani MG, Allingham RR, Shields MB. Histologic comparison of contact transcleral diode cyclophotocoagulation and endoscopic cyclophotocoagulation. Invest Ophthalmol Vis Sci. 1995;36(4):144-8. [Annual meeting. Fort Lauderdale, Florida, May 14-19, 1995. Abstracts].

11. Neely DE, Plager DA. Endocyclophotocoagulation for management of difficult pediatric glaucomas. J AAPOS. 2001;5(4):221-9.

12. Chen J, Cohn RA, Lin SC, Cortes AE, Alvarado JA. Endoscopic photocoagulation of the ciliary body for treatment of refractory glaucomas. Am J Ophthalmol. 1997;124(6):787-96.

13. Gayton JL, Van Der Karr M, Sanders V. Combined cataract and glaucoma surgery: trabeculectomy versus endoscopic laser cycloablation. J Cataract Refract Surg. 1999;25(9):1214-9.

14. Lima FE, Carvalho DM, Beniz J, Ávila M. Ciclofotocoagulação endoscópica em glaucomas refratários. Rev Bras Oftalmol. 1997;56(6):387-93.

Reprints requests to:

Francisco E. Lima, MD

Avenida T-2 número 401, Setor Bueno

CEP: 74210-010, Goiânia (GO), Brazil

Phone: 55-62-32525590, Fax: 55-62-32928828

e-mail: flimacbco@uol.com.br 